\title{
Comparison of artificial screening methods for evaluation of resistance to Fusarium wilt disease of castor (Ricinus communis L.)
}

\section{G.P. Gangwar*}

Castor and Mustard Research Station, S.D. Agricultural University, Sardarkrushinagar385506 (Gujarat), India

\section{A.G. Desai}

Castor and Mustard Research Station, S.D. Agricultural University, Sardarkrushinagar385506 (Gujarat), India

${ }^{*}$ Corresponding author. E-mail: gokilpatho@gmail.com

\begin{abstract}
This study was carried out to compare two artificial screening methods viz. Soil Infestation method (SIM) and root dip inoculation technique (RDIT), under glasshouse conditions for the screening of resistant to Fusarium wilt. Both the artificial screening methods; SIM and RDIT were statistically similar in respect of wilt incidence. However, the reaction exhibited by the castor genotypes was varied with artificial screening methods. Mean wilt incidence obtained through SIM (53.9\%) was higher as compared to RDIT (44.8\%). All the genotypes exhibited comparatively higher wilt incidence when screened through SIM as compared to RDIT. Genotype DCS 9 exhibited resistant reaction (15.8\%) when screened through RDIT but was moderately resistant (32.5\%) when screened through SIM. It was concluded that SIM could also be used for screening of castor genotypes for the resistance to Fusarium wilt disease. However, lower level of resistance could be evaluated efficiently with saving 8-10 days through RDIT as compared to soil infestation method.
\end{abstract}

Keywords: Castor, Fusarium wilt, Root dip inoculation technique, Screening methods, Soil infestation method.

\section{INTRODUCTION}

Castor (Ricinus communis L.) is the most important non-edible oilseed crop with immense industrial and commercial values which is widely used as a lubricant in high speed engines and aeroplanes; an important ingredient in manufacture of soaps, printing inks, varnishes, transparent paper, linoleum and plasticizers (Caupin, 1997) and it also a medicinally important oil seed crop (Ganeshkumari et al., 2008; Marwat et al., 2017). Castor belonging to family Euphorbiaceae is found across all tropical and sub-tropical regions of the world (Weiss, 2000). Castor has the ability to grow under low rainfall and low fertility conditions and is most suitable for dry land farming. It grows as an indeterminate annual or perennial crop depending on climate and soil types in tropical, sub-tropical and warm temperate regions in the world. It can be grown productively on underutilized marginal uplands. India is the world leader with regards to area, production and productivity. In India, Gujarat is leading castor growing state, contributing around $82 \%$ of total production in the country and has established a virtual monopolistic grip on the

\section{Article Info}

DOI:10.31018/jans.v10i4.1917 Received: October 9, 2018

Revised: November 4, 2018

Accepted: November 11, 2018

\section{How to Cite}

Gangwar, G.P. and Desai, A.G. (2018). Comparison of artificial screening methods for evaluation of resistance to Fusarium wilt disease of castor (Ricinus communis L.). Journal of Applied and Natural Science, 10(4): 1192-1195 
wilt sick plot methods for field screening and root dip inoculation technique for artificial screening under glass house conditions (Kumar et al., 2015). Present study was carried out to compare two artificial screening methods i.e. root dip inoculation technique (RDIT) and soil infestation method (SIM) for evaluation of resistance to Fusarium wilt disease of castor.

\section{MATERIALS AND METHODS}

The experiment was conducted at Castor and Mustard Research Station, S.D. Agricultural University, Sardarkrushinagar (Gujarat) during 201516.

Root dip inoculation technique (RDIT): The technique standardized by Raoof and Rao (1996) and Desai and Dange (2003) was followed with modifications. The pathogen was mass-multiplied on sorghum grain. Sorghum grain was soaked overnight in $2 \%$ sucrose solution and boiled till become soft. After draining excess sucrose solution, boil sorghum grains were filled in conical flask. These flasks were plugged with nonobservant cotton and wrapped with butter paper which was followed by sterilization through autoclaving. Inoculation of these flasks was done with $5 \mathrm{~mm}$ bits cut from of actively growing colony, under aseptic conditions and incubated in BOD incubator at $28 \pm 2{ }^{\circ} \mathrm{C}$ temperature for $12-15$ days. Conidia was harvested in sterilised distilled water, concentration of conidia was quantified using haemetocytometer and then its concentration was adjusted at $10^{6}$ conidia/ml suspension by diluting with sterilised distilled water. Castor seedlings of test genotypes were raised on coco pith and coarse sand $(1: 1 \mathrm{v} / \mathrm{v})$. Seeds of test genotypes were surface sterilized with 2.5 per cent sodium hypochlorite solution for five minutes and then single seed was sown in each well of nursery trays. 10-12 days old seedlings were uprooted, their roots were clipped from distal $1 / 3^{\text {rd }}$ end. Clipped roots were dipped in conidia suspension for 60 seconds and 10 seedlings were transplanted with maintaining equidistance in the pots filled with sterilized soil and irrigated immediately after transplanting. Two replications of each treatment were maintained. Tap water is used for irrigation in nursery trays and pots as and when needed. After 30 days of transplanting, mean wilt incidence was recorded.

Soil infestation method (SIM): The pathogen was mass-multiplied on coarse sand $(90 \%)$ and maize meal $(10 \%)$ medium. Both ingredients (900 $\mathrm{g}$ coarse sand $+100 \mathrm{~g}$ maize meal) and $150 \mathrm{ml}$ water were mixed thoroughly and filled in conical flasks. These flasks were plugged with nonobservant cotton and wrapped with butter paper which was followed by sterilization through autoclaving. Inoculation of these flasks was done with $5 \mathrm{~mm}$ bits cut from of actively growing colony, under aseptic conditions and incubated in BOD incubator at $28 \pm 2{ }^{\circ} \mathrm{C}$ temperature for $20-25$ days. After incubation, colonised sand maize meal medium taken out of flasks and dried under shed. Fifty gram of this inoculum was mixed with 1000 gram of sterilized soil thoroughly and filled in pots. Seeds of test genotypes were surface sterilized with 2.5 per cent sodium hypochlorite solution for five minutes. Twenty seeds were sown with maintaining equidistance in each pot and after germination, ten seedlings were maintained in each pot. Two replications of each treatment were maintained. Tap water is used for irrigation as and when needed. Wilt incidence was recorded after 30 days of sowing. Statistical analysis of the data obtained from experiment was done using appropriate programme as per the requirement of the experiment. The critical difference (CD) was calculated at $5 \%$ level of significance for comparison of difference between the means of different treatments. Disease progress curves were developed by plotting disease incidence (\%) against time. Area under disease progress curve (AUDPC) was calculated by using following formula (Shanner and Finney, 1977):

$$
\text { AUDPC }=\frac{\left(\frac{D_{1}+D_{2}}{2} \times T\right)+\left(\frac{D_{2}+D_{3}}{2} \times T\right) \ldots \ldots . .\left(\frac{D_{n-1}+D_{n}}{2} \times T\right)}{n-1}
$$

Where,

$\mathrm{D}=$ Mean wilt incidence (\%) at different time intervals $\left(D_{1} D_{2} D_{3} \ldots \ldots . .\right.$. - $\left._{n}\right)$

$\mathrm{T}=$ Time interval (days) between two observations

$\mathrm{n}=$ Total number of observations

\section{RESULTS AND DISCUSSION}

The analysis of data obtained from evaluation of resistance to Fusarium wilt disease of castor revealed that both the artificial screening methods; SIM and RDIT were statistically similar (Table 1). However, the reaction castor genotypes (Table 2) exhibited with artificial screening methods was varied. Mean wilt incidence obtained through SIM (53.9\%) was higher as compared to RDIT (44.8 $\%)$.

Interaction of screening methods and genotypes was also non-significant. However, all the genotypes exhibited comparatively higher wilt incidence when screened through SIM as compared to RDIT it may be due to the mixing of inoculum with soil so pathogen could infect the plant just after the germination at more tender stage. The reactions of castor genotypes were categorized on the basis of scale presented in Table 2. Genotype DCS 9 exhibited resistant reaction $(15.8 \%)$ when screened through RDIT but was moderately resistant $(32.5 \%)$ when screened through SIM. Similarly, Genotype DCS 107 exhibited moderately resistant $(23.5 \%)$ reaction when screened 
Gangwar, G.P. and Desai, A.G. / J. Appl. \& Nat. Sci. 10 (4): 1192-1195 (2018)

Table 1. Comparison of two artificial screening methods viz. soil infestation method and root dip inoculation technique for the evaluation of resistance to Fusarium wilt of castor.

\begin{tabular}{|c|c|c|c|c|c|c|}
\hline \multirow{2}{*}{$\begin{array}{l}\text { S. } \\
\text { N. }\end{array}$} & \multirow{2}{*}{$\begin{array}{l}\text { Castor } \\
\text { Genotypes }\end{array}$} & \multicolumn{2}{|c|}{ Soil Infestation Method (SIM) } & \multicolumn{2}{|c|}{$\begin{array}{l}\text { Root Dip Inoculation Technique } \\
\text { (RDIT) }\end{array}$} & \multirow[t]{2}{*}{ Mean } \\
\hline & & Plant Stand & Wilt incidence (\%) & Plant Stand & Wilt incidence (\%) & \\
\hline 1. & Kranti & 20 & $42.5(40.6)$ & 19 & $39.5(38.6)$ & $40.8(39.6)$ \\
\hline 2. & DCS 9 & 20 & $32.5(34.7)$ & 19 & $15.8(18.6)$ & $23.8(26.7)$ \\
\hline 3. & $48-1$ & 20 & $20.0(26.5)$ & 19 & $0.0(4.1)$ & $10.0(15.3)$ \\
\hline 4. & JI 35 & 20 & $100.0(85.9)$ & 20 & $90.0(74.7)$ & $95.0(80.3)$ \\
\hline 5. & DCS 107 & 18 & $41.5(40.0)$ & 17 & $24.5(29.6)$ & $33.0(34.8)$ \\
\hline 6. & VP 1 & 19 & $86.5(69.5)$ & 20 & $100.0(85.9)$ & $93.3(77.7)$ \\
\hline \multicolumn{2}{|c|}{ Mean } & - & $53.8(49.6)$ & - & $44.8(41.9)$ & $49.3(45.7)$ \\
\hline \multirow{3}{*}{\multicolumn{2}{|c|}{ CD at $5 \%$}} & \multicolumn{4}{|c|}{ Methods $(A)$} & ns \\
\hline & & \multicolumn{4}{|c|}{ Genotypes (B) } & 13.7 \\
\hline & & \multicolumn{4}{|c|}{$A \times B$} & Ns \\
\hline
\end{tabular}

* Mean of two replications; Figures in parentheses are angular transformed values.

Table 2. Categorization of castor genotype reaction to Fusarium wilt of castor (Mayee and Datar, 1986).

\begin{tabular}{ll}
\hline Wilt incidence (\%) & Category \\
\hline 0.0 & Highly resistance \\
$0.01-20.0$ & Resistant \\
$20.1-40.0$ & Moderately resistant \\
$40.1-60.0$ & Moderately susceptible \\
$60.1-80.0$ & Susceptible \\
$>80.0$ & Highly susceptible \\
\hline
\end{tabular}

through RDIT, but was moderately susceptible $(41.7 \%)$ when screened through SIM. Genotype Kranti exhibited moderately resistant (39.5\%) reaction when screened through RDIT but was moderately susceptible $(42.5 \%)$ when screened through SIM. Genotype 48-1 exhibited highly resistant $(0.0 \%)$ reaction when screened through RDIT, but was resistant $(20.0 \%)$ when screened through SIM. Though, both methods were statistically similar but reaction exhibited by the castor genotypes was varied. All the castor genotypes exhibited higher wilt incidence when screened through SIM as compared to RDIT, except VP 1 where lower wilt incidence (86.5\%) was recorded with SIM as compared to RDIT (100.0\%). Wilt disease progress curve prepared for both methods and leg phase between 15 days to 20 days

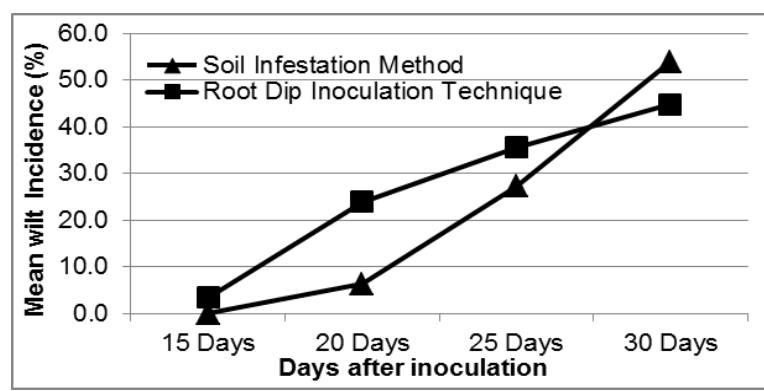

Fig. 1. Effect of screening methods viz. soil infestation method and root dip inoculation technique on Progress of Fusarium wilt disease on castor.

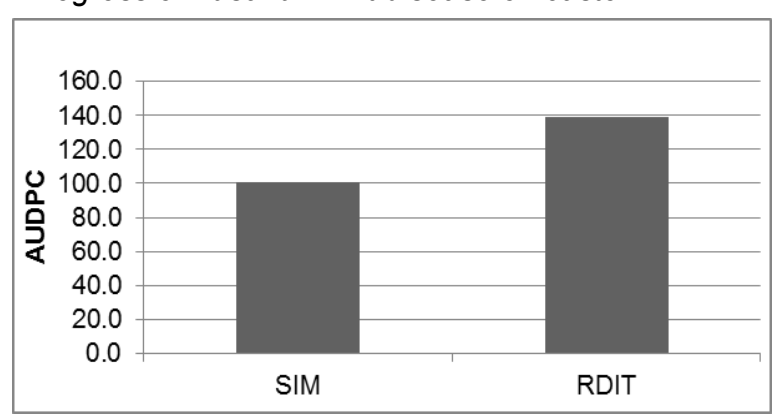

Fig. 2. Effect of screening methods viz. soil infestation method and root dip inoculation technique on Area Under Disease Progress Curve (AUDPC) of Fusarium wilt disease on castor.

Table 3. Difference between soil infestation method (SIM) and root dip inoculation technique (RDIT) for the evaluation of resistance to Fusarium wilt of castor.

\begin{tabular}{|c|c|c|c|}
\hline $\begin{array}{l}\text { S. } \\
\text { N. }\end{array}$ & Characteristics & $\begin{array}{l}\text { Soil infestation Meth- } \\
\text { od (SIM) }\end{array}$ & $\begin{array}{l}\text { Root dip inoculation technique } \\
\text { (RDIT) }\end{array}$ \\
\hline 1. & Medium for mass multiplication & $\begin{array}{l}\text { Sand + maize meal } \\
(9: 1 \mathrm{w} / \mathrm{w})\end{array}$ & $\begin{array}{l}\text { Sorghum grains amended with } 2 \% \\
\text { sucrose solution }\end{array}$ \\
\hline $\begin{array}{l}2 . \\
3 . \\
4 . \\
5 .\end{array}$ & $\begin{array}{l}\text { Days of mass multiplication } \\
\text { Medium for raising seedling } \\
\text { Days taken to raise seedling } \\
\text { Dominant Inoculum type }\end{array}$ & $\begin{array}{l}20-25 \text { days } \\
- \\
- \\
\text { Chlamydospores }\end{array}$ & $\begin{array}{l}12-15 \text { days } \\
\text { Coco pith and coarse sand }(1: 1 \mathrm{v} / \mathrm{v}) \\
10-15 \text { days } \\
\text { Micro and macro conidia }\end{array}$ \\
\hline 6. & Inoculum load & $\begin{array}{l}\text { Not well defined }(50 \mathrm{~g} / \\
\text { kg soil) }\end{array}$ & $\begin{array}{l}\text { Well defined } \\
\left(10^{6} \text { conidia } / \mathrm{ml}\right)\end{array}$ \\
\hline 7. & Time of Inoculation (For each seedling) & Not uniform & Uniform \\
\hline 8. & Days of disease appearance & $\begin{array}{l}\text { After } 18 \text { days of sow- } \\
\text { ing }\end{array}$ & After 10 days of inoculation \\
\hline $\begin{array}{l}9 . \\
10 . \\
11 .\end{array}$ & $\begin{array}{l}\text { Progress of disease } \\
\text { Days of final observation } \\
\text { Total days required for evaluation }\end{array}$ & $\begin{array}{l}\text { Very fast } \\
30 \text { DAS } \\
50-55 \text { days }\end{array}$ & $\begin{array}{l}\text { fast } \\
30 \text { DAT } \\
42-45 \text { days }\end{array}$ \\
\hline
\end{tabular}


after inoculation was noticed with SIM which was followed by log phase ( 20 days to 30 days after inoculation) whereas with RDIT, a extended log phase (15 days to 30 days after inoculation was observed (Figure 1). Area under disease progress curve (AUDPC) calculate with SIM (100.8 units) was lower (Figure 2) as compared to RDIT (139.4 units).

Differences between both methods viz. soil infestation method (SIM) and root dip inoculation technique (RDIT) are presented in Table 3.

It was noted during mass multiplication of wilt pathogen that on sorghum grains, mostly micro and macro conidia were produced, whereas on sand maize meal medium mostly chlamydospores were produced. This fact could explain the late appearance of Fusarium wilt disease with SIM as compared to RDIT. Concentration of inoculum was well defined $\left(10^{6}\right.$ conidia $\left./ \mathrm{ml}\right)$ and uniform on each seedling in RDIT. In RDIT healthy seedling of each genotype was raised in advance and then inoculation of 10-15 days old seedlings was performed by root dip inoculation technique which was followed by transplanting, whereas in SIM there is chance of infection of each seedling just after germination at more tender stage because inoculum is mixed directly into the soil. This could be explain the higher incidence and very fast progress (Figure 1) of Fusarium wilt disease recorded with SIM. Raoof and Rao (1996) concluded that by RDIT, lowest form of resistance can be expressed which may be exploited in the breeding program for incorporating this into a high yielding variety. Advanced breeding lines screened at field level in wilt sick plot are simultaneously screened using RDIT for confirmation for wilt resistance for effective screening of castor genotypes. This study is in accordance with finding of Kumar et al., (2015) in which they concluded that root dip inoculation technique is also useful in the study of pathogenic variability among $F$. oxysporum f. sp. ricini isolates.

\section{Conclusion}

It may be concluded that SIM could also be used as alternative of RDIT for screening of castor genotypes for the resistance to Fusarium wilt disease. However, the lower level of resistance could be evaluated efficiently with saving 8-10 days through RDIT as compared to soil infestation method.

\section{ACKNOWLEDGEMENTS}

The authors are highly thankful to S.D. Agricultur- al University, Sardarkrushinagar and ICAR-Indian Institute of Oilseed Research, Hyderabad for providing fund, facilities and guidance.

\section{REFERENCES}

1. Caupin, H.J. (1997). Lipid technologies and applications. In: Products from castor oil: Past, present and future. Gunstone, F.D. and Padley, F.B. (eds.) Marcel Dekker, New York. pp. 787-795.

2. Dange, S.R.S. (2003). Wilt of castor- An overview. J. Mycol. Pl. Pathol. 33: 333-339.

3. Dange, S.R.S., Desai, A.G. and Patel, D.B. (1997). Management of wilt of castor in Gujarat State in India. In: Proceedings of International Conference on Integrated Plant Disease Management for Sustainable Agriculture. 10-15 Nov. IARI, New Delhi, India. $107 \mathrm{pp}$.

4. Desai, A.G. and Dange, S.R.S. (2003). Standardization of root dip inoculation technique for screening of resistance to castor wilt. J. Mycol. PI. Pathol. 33(1): 73-75.

5. Ganeshkumari, K., Ganesan, M. and Jayabalan, N. (2008). Somatic embryogenesis and plant regeneration in Ricinus communisL. Biol.Plant. 52: 17-25.

6. Kumar, M.V.N., Gourishankar, V., Ramya, V., Priya, P.B., Ramanjaneyulu, A.V., Seshu, G. and Reddy, V.V. (2015). Enhancing Castor (Ricinus communis L.) Productivity through genetic improvement for Fusarium wilt resistance- A review. Industrial Crops and Products, 67: 330-335.

7. Marwat, S.K., Fazal-ur-Rehman, Khan, A.E., Baloch, M.S., Sadiq M., Ullah, I., Javaria, S. and Shaheen S. (2017) Ricinus communis: Ethnomedicinal uses and pharmacological activities. Pak. J. Pharm. Sci., 30(5): 1815-1827.

8. Mayee, C.D. and Datar, V.V., (1986). Phytopathometry. Technical Bulletin 1, Marathwada Agricultural University, Parbhani, India. pp. 218.

9. Moshkin, V.A. (1986). Castor. Amerind Publishing Co. Pvt. Ltd. New Delhi. pp. 315.

10.Niks, R.E., Ellis, P.R. and Parlevliet, J.E. (1993). Resistance to parasites. In: Plant breeding: principles and prospects. Hayward, M.D., Bosemark, N.O. and Romagosa, I. (eds). Chapman and Hall, London. p. 422-447.

11.Raoof, M.A. and Rao, T.G.N. (1996). A simple screening technique for early detection of resistance to castor wilt. Ind. Phytopathol. 49: 389-392.

12.Raoof, M.A. and Rao, T.G.N. (1999). Castor diseases and their integrated management. In: IPM Systems in Agriculture. Upadhyay, R., Mukherji, K.G. and Rajak, R.L. (eds.) Vol. 5 (Oilseeds). Aditiya Books Pvt. Ltd. New Delhi. p. 559-574.

13.Shanner, G. and Finney, R.F. (1977). The effect of nitrogen fertilization on the expression of slowmildewing resistance in Knox Wheat. Phytopathol. 67: 1051-1056.

14.Weiss, E.A. (2000). Oilseed Crops. 2nd ed. Blackwell Science, Oxford. 